\title{
A Study on the Trend of Domestic Waste Generation and the Recognition of Recycling Priorities in Korea
}

\author{
Seok-ho Jung ${ }^{1}$, Mee-hye Lee ${ }^{1}$, Seong-ho Lee ${ }^{2}$ and Ji Whan Ahn ${ }^{2, *}$ \\ 1 Department of Earth and Environmental Sciences, Korea University, Seoul 02841, Korea; \\ refresh@korea.ac.kr (S.-h.J.); meehye@korea.ac.kr (M.-h.L.) \\ 2 Center for Carbon Mineralization, Mineral Resources Research Division, Korea Institute of Geoscience and \\ Mineral Resources (KIGAM), 124 Gwahak-ro, Yuseong-gu, Daejeon 34132, Korea; mujok821@kigam.re.kr \\ * Correspondence: ahnjw@kigam.re.kr; Tel.: +82-42-868-3578
}

Citation: Jung, S.-h.; Lee, M.-h.; Lee, S.-h.; Ahn, J.W. A Study on the Trend of Domestic Waste Generation and the Recognition of Recycling

Priorities in Korea. Sustainability 2021, 13, 1732. https://doi.org/10.3390/ su13041732

Academic Editor: Vladimir Strezov

Received: 9 December 2020

Accepted: 2 February 2021

Published: 5 February 2021

Publisher's Note: MDPI stays neutral with regard to jurisdictional claims in published maps and institutional affiliations.

Copyright: (c) 2021 by the authors. Licensee MDPI, Basel, Switzerland. This article is an open access article distributed under the terms and conditions of the Creative Commons Attribution (CC BY) license (https:/ / creativecommons.org/licenses/by/ $4.0 /)$.

\begin{abstract}
In September 2015, the United Nations included 'sustainable consumption and production' as part of its 12th goal of sustainable development. The EU announced its Circular Economic Package in December 2015 to move from the existing linear economic structure to the net environmental system. Recycling of household waste has become more significant as a circular economic policy has been implemented to reflow waste into the economy through recycling worldwide. In this study, Korea's household waste generation for 20 years from 1998 to 2017 was analyzed through statistical techniques. Waste generation tended to increase in the order of plastics and cans, and papers tended to decrease. The amount of bottle wastes has been on the decline after increasing. A questionnaire survey on recycling priority was conducted on 261 people, including participants in the EARTH-2019 recycling experience hall, using the analytic hierarchy process (AHP) technique. According to the survey, the recycling priorities of six types of household waste are (first) plastic, (second) cans, viny, scrap metals, (third) paper, and (fourth) bottles. Statistical analysis of mid- to long-term household waste generation and AHP-based household waste recycling priority survey results can be used as basic data, such as environmental analysis in Korea's recycling-related policies and research.
\end{abstract}

Keywords: household waste; recycling; circular economy; household waste recycling priority survey; AHP

\section{Introduction}

Numerous recycling policies are being proposed for sustainable development worldwide. The United Nations (UN) included sustainable consumption and production as one of the Sustainable Development Goals (SDGs) as its 12th task in September 2015, and the European Union (EU) announced the circular economy package in December 2015 to shift to a circular economy from a linear economy [1].

Korea, China, and Japan are also implementing recycling-related policies, such as a circular economy. Korea enacted the Framework Act on Resource Circulation, which was implemented in 2018, and establish the 1st Master Plans for Resources Circulation, which included the country's mid- to long-term policy direction and detailed strategies for realizing the circular economy. China presented a definite action plan for promoting circular economy in The Circular Economy Development Strategy and the Near-Term Action Plan in 2013, and Japan presented an integrated response to creating a sustainable society in The 4th Fundamental Plan for Establishing a Sound Material-Cycle Society in 2018 [1-3].

Likewise, as the circular economy policy that recycles waste to the economy through recycling has been promoted around the world, recycling of household waste has become more meaningful. According to data released by the Ministry of Environment in 2018 on the 1st Basic Plan for Resource Circulation, the total amount of waste generated in Korea as 
of 2016 was 429,139 tons/day, of which 53,772 tons/day of domestic waste accounted for about $12.5 \%$. This is the second-largest proportion after construction and workplace waste.

Of the 17 major local governments' household waste in Korea, daily plastic emissions reached 4629 tons in 2017, up about 1.8 times from 2562 tons per day in 1998, and has been steadily increasing. In recycling policies, such as EU COMMISSION's EU Circular Economy Action Plan and Korea's The 1st Master Plans for Resources Circulation, policies that put plastic as a major priority among household waste are being promoted. In 2017 and 1998, for a simple comparison of the scale of daily generations of typical household waste, paper was about 0.8 times, glass bottles were about 1.3 times, and cans were about 1.1 times, indicating that the generation of plastics increased relatively rapidly. It can be seen that these conditions were considered and reflected in the policy [1,4-33].

Korea has procedures for collecting public opinion when establishing policies and systems. In accordance with Article 2 of the Administrative Procedure Act, when there are conflicting opinions between members on a specific project, policy, system, etc. through a public hearing, the opinions of experts, stakeholders, and the general public are collected to adjust the conflicting opinions, or it collects the opinions of the people through the public forum. In 2017, the Ministry of Public Administration and Security revised the Regulations on the Promotion of Administrative Efficiency and Collaboration to collect the public's creative opinions and promote the efficiency of administrative operations [34-36].

The survey is a general method of collecting opinions. In order to materialize and objectify decision making, a questionnaire is planned and surveyed through the Delphi technique or the stratified analysis technique [37-40].

This study analyzes household waste discharge trends through statistical analysis, such as correlation analysis, the multiple regression analysis (MRA), and trend line analysis, on household waste data from 1998 to 2017 in 17 major local governments in Korea. In addition, a survey was conducted on 261 people nationwide, such as EARTH-2019 attendees, and the priority of recycling household waste was derived through the analytic hierarchy process (AHP) technique. Through this, it is intended to be used as basic data, such as environmental analysis, in establishing and researching recycling-related policies in Korea.

\section{A Study of Methods}

\subsection{Data Collection}

This study analyzed the data on household waste generation from 1998 to 2017 in 17 major regions of South Korea and on 261 survey responses. The household waste data were collected from government and related organizations' information systems, including the Korean Statistical Information Service, the Korea Resource Recirculation Information System, and the Korea Waste Association. The survey responses were collected from recycling-related booths at the international forum, the international conference, and large discount stores during July to October 2019. Among the 3000 visitors to the booths, 261 people responded to the survey. Figure 1 shows the process of research $[41,42]$. 


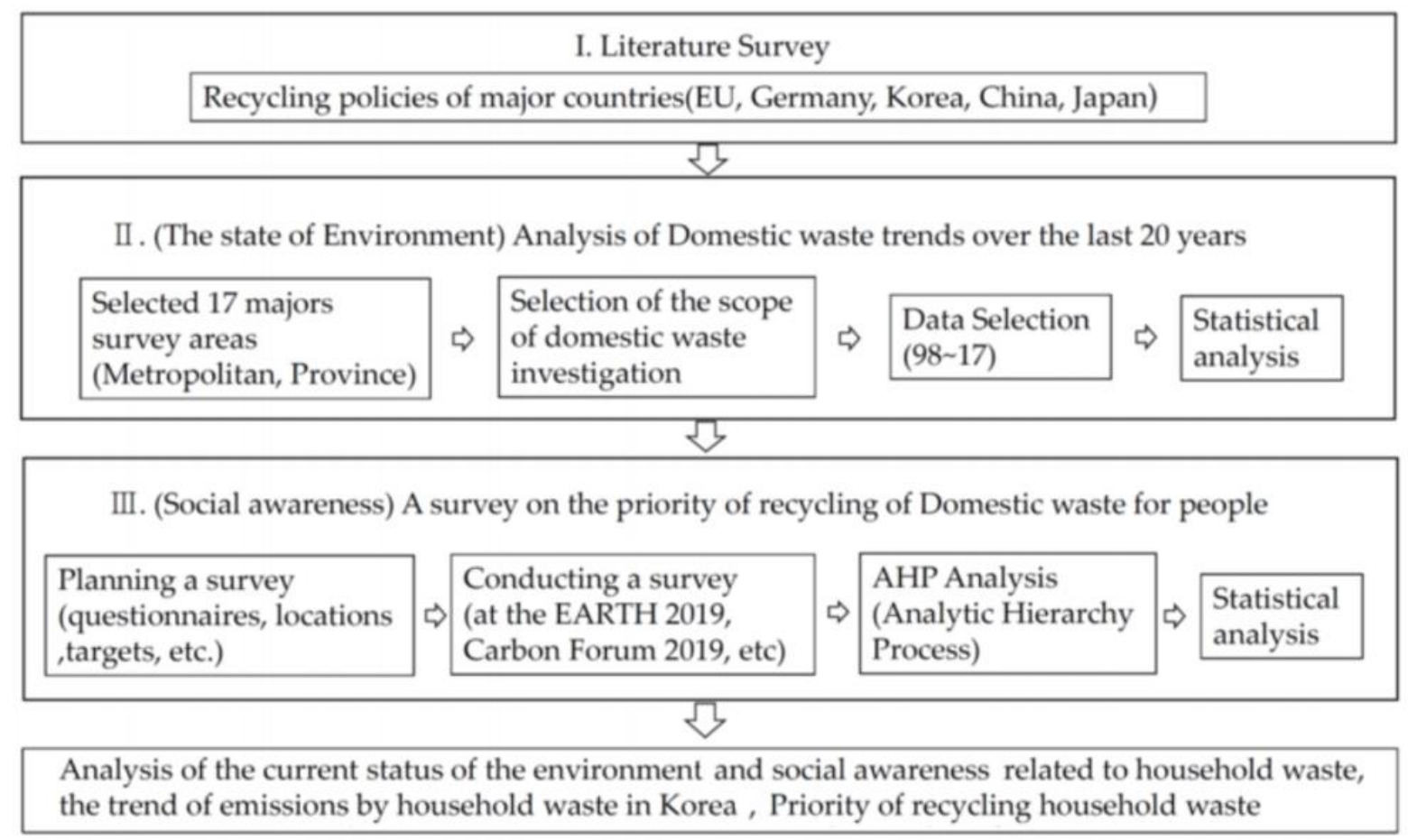

Figure 1. Process of research.

\subsection{Literature Review}

Before carrying out the analysis of household waste trends and of the priority survey, we investigated the current status of domestic waste-related policies in the EU, China, Japan, and Korea. The literature was collected from academic DB and related public institution websites, such as SCOPUS, Web of Science, National Digital Science Library (NDSL), DBpia, Korean Studies Information Service System (KISS), and Google Scholar. A representative recycling-related policy is the European Commission's Circular Economic Package adopted in December 2015. It became a major point for the transition from the existing linear economic structure to the circular economy. The EU announced its plastic response strategy, A European Strategy for Plastics in a Circular Economy, in 2018. As an extension of this, the New Circular Economic Action Plan was recently announced in 2020. Korea enacted the Framework Act on Resource Circulation, which became operative from 2018. Additionally, the government established the National Resource Circulation Basic Plan, which includes the national mid- to long-term policy directions and detailed strategies for realizing the circular economy. Table 1 shows the recycling policies in major countries. These countries have joined the circle economy paradigm, which is consumed, recovered, and recycled in a linear economy that is discarded after existing consumption. Among them, EU and Korea included waste plastic-related management strategies among household waste as their policies [1-3,22,26-32].

Table 1. Recycling policies in major countries (Adapted from Korea Environmental Industry and Technology Institute, 2019).

\begin{tabular}{|c|c|c|}
\hline Country & Policy Name (Year) & Current Status \\
\hline \multirow{3}{*}{ EU } & Circular economy package (2015) & $\begin{array}{l}\text { Establish a plan related to the preparation of requirements for } \\
\text { product resource efficiency and material efficiency. }\end{array}$ \\
\hline & $\begin{array}{l}\text { A European Strategy for Plastics in a } \\
\text { Circular Economy (2018) }\end{array}$ & $\begin{array}{l}\text { - } \quad \text { Promote recycling of plastic containers in EU markets by } 2030 \\
\text { - } \quad \text { Reduce disposable plastic products and promote regulations on the } \\
\text { use of microplastics. }\end{array}$ \\
\hline & $\begin{array}{l}\text { New Circular Economy Action Plan } \\
(2020)\end{array}$ & $\begin{array}{ll}\text { - } & \text { Standardize sustainable products } \\
\text { - } & \text { Cyclical economicization by major industrial sectors } \\
\text { - } & \text { Minimize waste and create value }\end{array}$ \\
\hline
\end{tabular}


Table 1. Cont.

\begin{tabular}{|c|c|c|}
\hline Country & Policy Name (Year) & Current Status \\
\hline & $\begin{array}{ll}- & \text { Germany Adopts Persistent } \\
& \text { National Growth Strategy (2002) } \\
\text { - } & \text { Resource Efficiency Program (2012) } \\
\text { - } & \text { Second Resource Efficiency } \\
& \text { Program (2016) }\end{array}$ & $\begin{array}{l}\text { - Twice the productivity of energy and raw materials by } 2020 \\
\text { (Four-fold improvement in long-term goals) } \\
\text { Ensuring sustainable supply of raw materials, improving resource } \\
\text { efficiency in production, and increasing consumption to improve } \\
\text { resource efficiency. }\end{array}$ \\
\hline Korea & $\begin{array}{l}\text { Master Plans for Resources Circulation } \\
(2018-2027)\end{array}$ & $\begin{array}{l}\text { - } \quad \text { Goal of Zero Waste Social Settlement } \\
\text { - } \quad \text { Goal of achieving } 20.3 \% \text { resource circulation rate and } 26 \% \text { reduction } \\
\text { in final landfill capacity }\end{array}$ \\
\hline China & $\begin{array}{l}\text { - } \quad \text { The Circular Economy } \\
\text { Development Strategy and the } \\
\text { Near-Term Action Plan (2013) } \\
\text { - } \quad \text { Waste Import Regulation (2017) }\end{array}$ & $\begin{array}{l}\text { - } \quad \text { Special plan for national cyclical economic development } \\
\text { - } \quad \text { Reviewing the industrial structure to promote resource circulation by } \\
2020 \text { (including suspension of illegal importers) }\end{array}$ \\
\hline Japan & $\begin{array}{l}\text { Basic Plan for the Promotion of } \\
\text { Circular Social Formation (2003) } \\
\text { The } 4 \text { th Fundamental Plan for } \\
\text { Establishing a Sound } \\
\text { Material-Cycle Society (2018) }\end{array}$ & $\begin{array}{l}\text { - } \quad \begin{array}{l}\text { Adopting resource productivity, circulation rate, final disposal } \\
\text { volume and target management as national indicators } \\
\text { - }\end{array} \text { Established in } 2003 \text { and revised every five years } \\
\text { - } \quad \text { Decoupling accelerated due to reduced resource consumption, } \\
\text { reduced final disposal, increased circulation, reduced pollutant } \\
\text { emissions, and increased GDP. } \\
\text { - Presenting an integrated response for sustainable social formation }\end{array}$ \\
\hline
\end{tabular}

\section{Method of Analysis of Data}

\subsection{Scope and Method of Analysis of Household Waste Trends}

This study calculated the emissions of household waste from 1998 to 2017 in Gangwondo, Gyeonggi-do, Gyeongsangnam-do, Gyeongsangbuk-do, Gwangju, Daegu, Daejeon, Busan Metropolitan City, Seoul Metropolitan Government, Sejong Special Self-Governing City, Ulsan Metropolitan City, Incheon Metropolitan City, Jeollanam-do, Jeollabuk-do, Jeju Special Self-Governing Province, Chungcheongnam-do, and Chungcheongbuk-do, which are 17 local autonomous entities that are Korean administrative regions. As shown in Figure 2, under the Wastes Control Act, which is overseen by the Ministry of Environment in Korea, waste is classified as household waste and industrial waste, and statistical data on household waste is usually managed as household waste along with industrial waste. In this study, paper, plastic, glass bottles, cans, etc., among the recyclable resources emissions from households of the general public, were limited to household wastes, excluding workplace waste, to compare the perceptions of the public's priority on recycling of household waste.

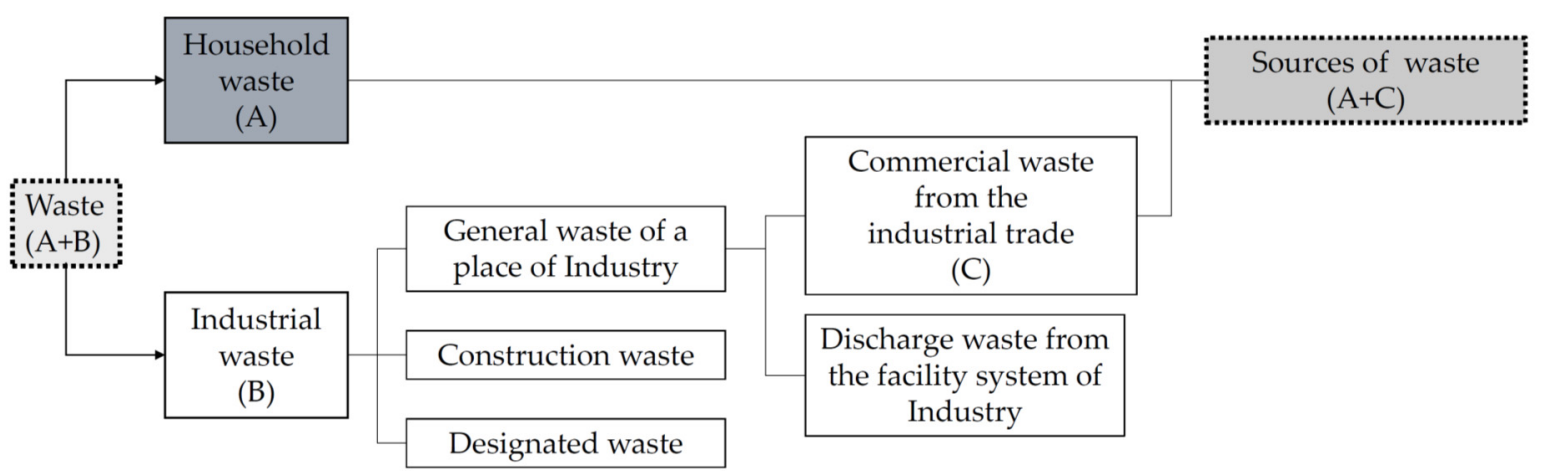

Figure 2. Waste classification in the Waste Management Act (Adapted from Ministry of Environment, 2017).

Using IBM SPSS statistics 25 and Microsoft Excel 2016, we checked the variability of the annual household waste generation (ton/day) in Korea over the past 20 years, and used analysis techniques, such as correlation analysis and regression analysis, to check the correlation between household waste emissions and the impact on overall emissions. 


\subsection{Scope and Method of the Survey on the Public Awareness of Recycling Priority}

This study included basic information, such as gender, age, marriage, number of family members (cohabitation, children), income level, and occupation, of 261 surveyors who attended recycling experience booths and participated in the survey, as well as information on recognition of the recycling priority for six types of household waste, including plastics, vinyl, scrap metals, cans, paper, and bottles.

An AHP analysis was conducted to investigate recycling priority recognition. The AHP analysis was developed in early 1970 by Professor Thomas Saaty of the University of Pennsylvania to streamline the decision-making process. It is a system that can comprehensively evaluate group intentions by reflecting various fields and evaluation criteria through a hierarchical analytical decision-making method, and is the most representative of the existing decision-making techniques. As shown in Table 2, opinions were collected through a questionnaire designed to enable dual comparison between household wastes. Using SPSS 25 and Excel 2016 for survey data, we derived the weighted recycling priority by the AHP method and quantified decision making to secure the reliability of AHP analysis, as a consistency index (CI) required. In general, through statistical verification, the threshold to guarantee the reliability of the CI was 0.1 , and statistical significance was secured by testing with items within $10 \%$ of the consistency ratio (CR) [43-48].

$$
\begin{gathered}
C I=\frac{\lambda \max -n}{n-1} \\
C R=\frac{C I}{R I}
\end{gathered}
$$

CR: Consistency Ratio, CI: Consistency Index, RI: Random Index

\begin{tabular}{|c|c|c|c|c|c|c|c|c|c|c|}
\hline \multicolumn{6}{|c|}{ Item 1 I Think Recycling Is More Important than Item 2.} & \multicolumn{5}{|c|}{ Item 2 Is More Important in Recycling than Item 1.} \\
\hline $\begin{array}{c}\text { Item } \\
1 .\end{array}$ & $\begin{array}{l}\text { Absolute } \\
\text { importance }\end{array}$ & $\begin{array}{c}\text { Very } \\
\text { strongly } \\
\text { Important }\end{array}$ & $\begin{array}{c}\text { Very } \\
\text { Important }\end{array}$ & $\begin{array}{l}\text { Slightly } \\
\text { important }\end{array}$ & $\begin{array}{l}\text { Both sides } \\
\text { Equivalence }\end{array}$ & $\begin{array}{c}\text { Slightly } \\
\text { import ant }\end{array}$ & $\begin{array}{c}\text { Very } \\
\text { Important }\end{array}$ & $\begin{array}{c}\text { Very } \\
\text { strongly } \\
\text { Important }\end{array}$ & $\begin{array}{c}\text { Absolute } \\
\text { importance }\end{array}$ & $\begin{array}{c}\text { Item } \\
2 .\end{array}$ \\
\hline
\end{tabular}

Table 2. Pairwise comparison model.

\section{Results}

\subsection{Trends in Korea's Household Waste Discharge in the Last 20 Years (1998-2017)}

Figure 3 shows the daily household waste emissions by year for the last 20 years in 17 major regions of Korea from 1998 to 2017. The daily emissions of major household wastes, such as paper, plastics, glass bottles, and cans, peaked at about 16,963 ton/day in 2003 and the lowest at about 14,655 ton/day in 2011, and slightly increased or decreased. The average household waste emissions in 17 major cities over 20 years were 9647.4 tons/day for paper, 3526.4 tons/day for plastic, 2070.2 tons/day for bottles, and 635.3 tons/day for cans. In the trend line analysis for each household waste, when $R^{2}$ was within the statistically significant range of 0.44 to 0.84 , the amount of discharge was upward in the order of plastics and cans, and the discharge of paper showed a downward trend. The Bottles showed a downward trend after the rise. Figures $4-7$ shows the amount of discharge by household waste including the trend line. 


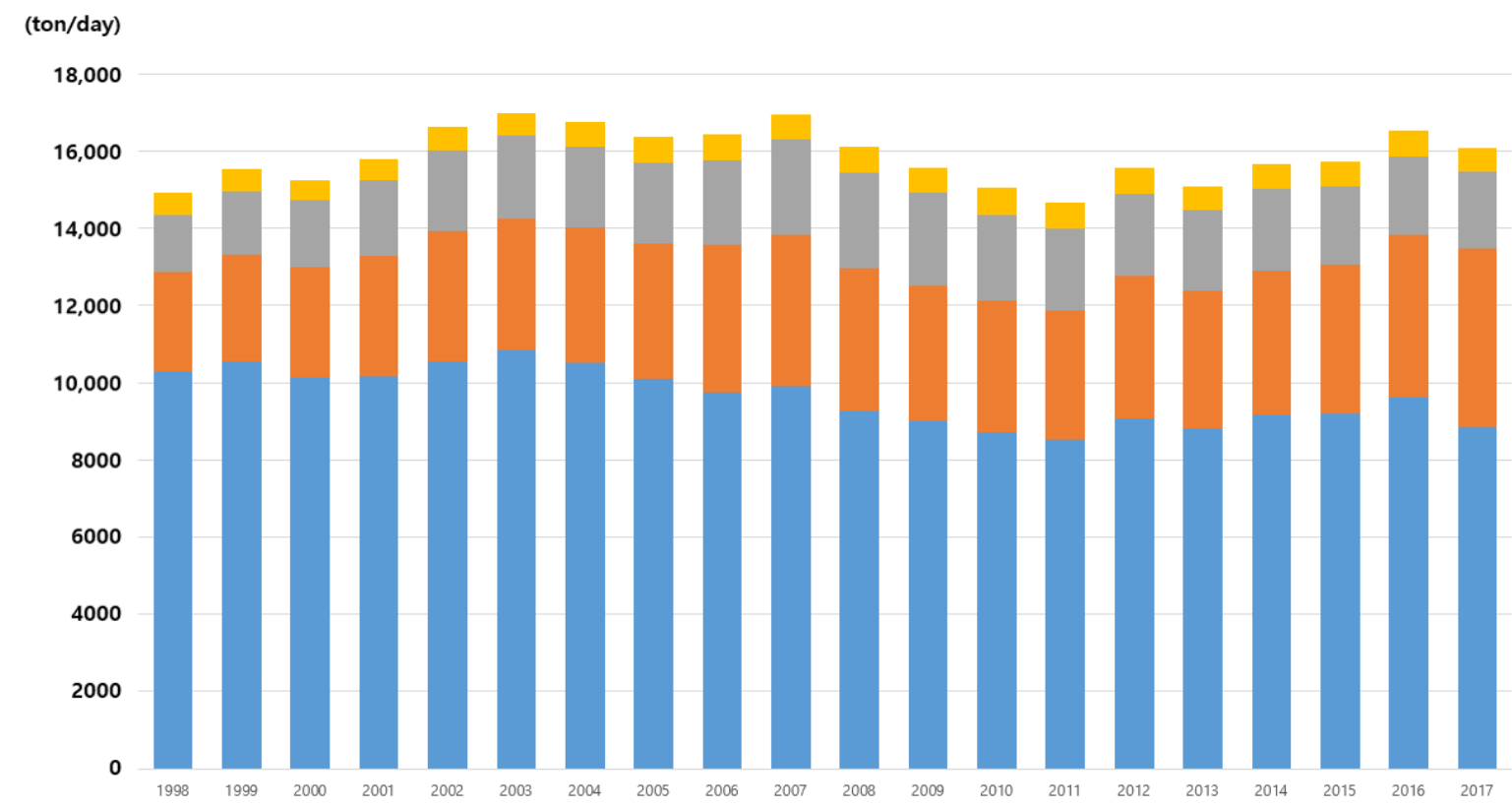

Figure 3. Trends in Korea's household waste discharge in the last 20 years (1998-2017).

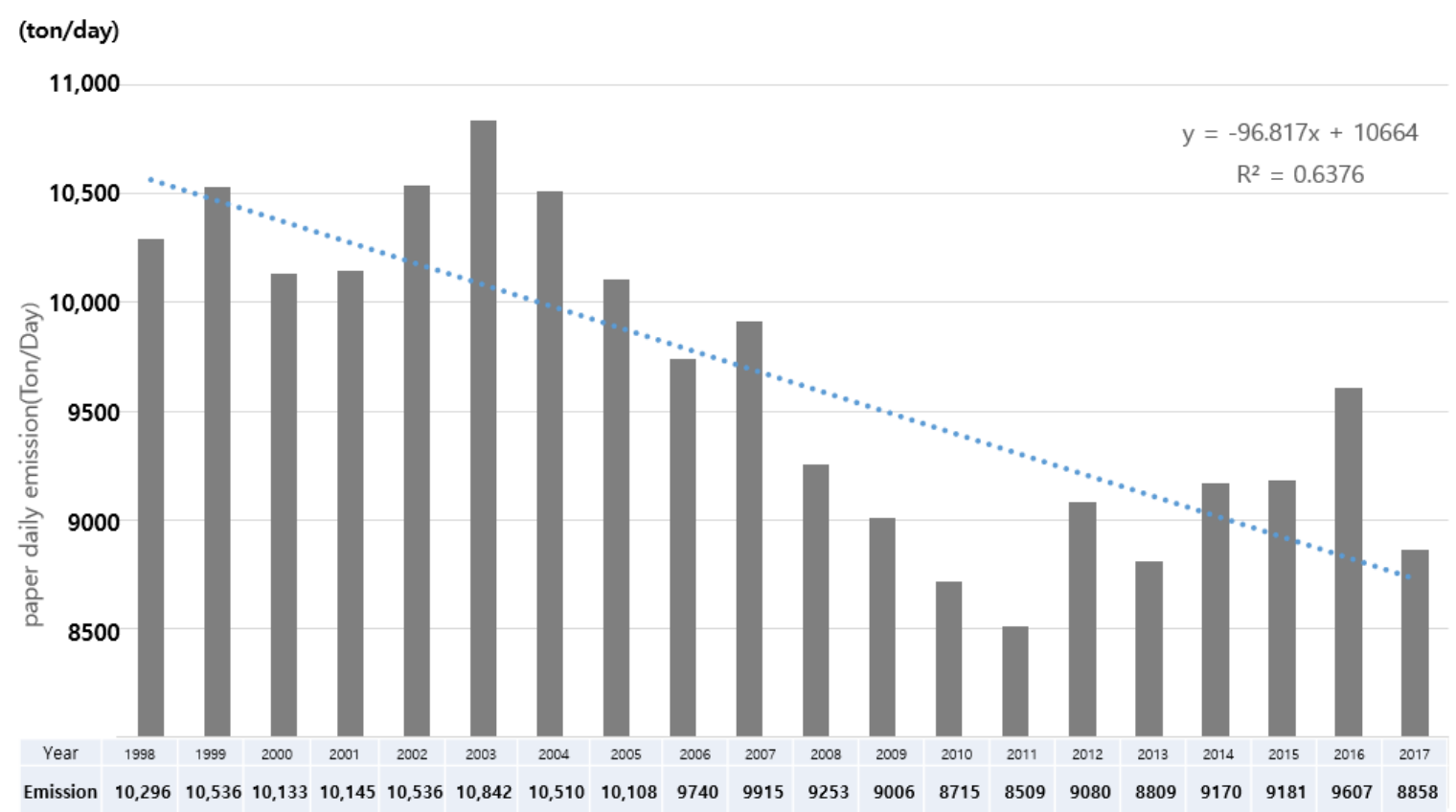

Figure 4. Trends in domestic paper emissions in Korea over the last 20 years (1998-2017). 


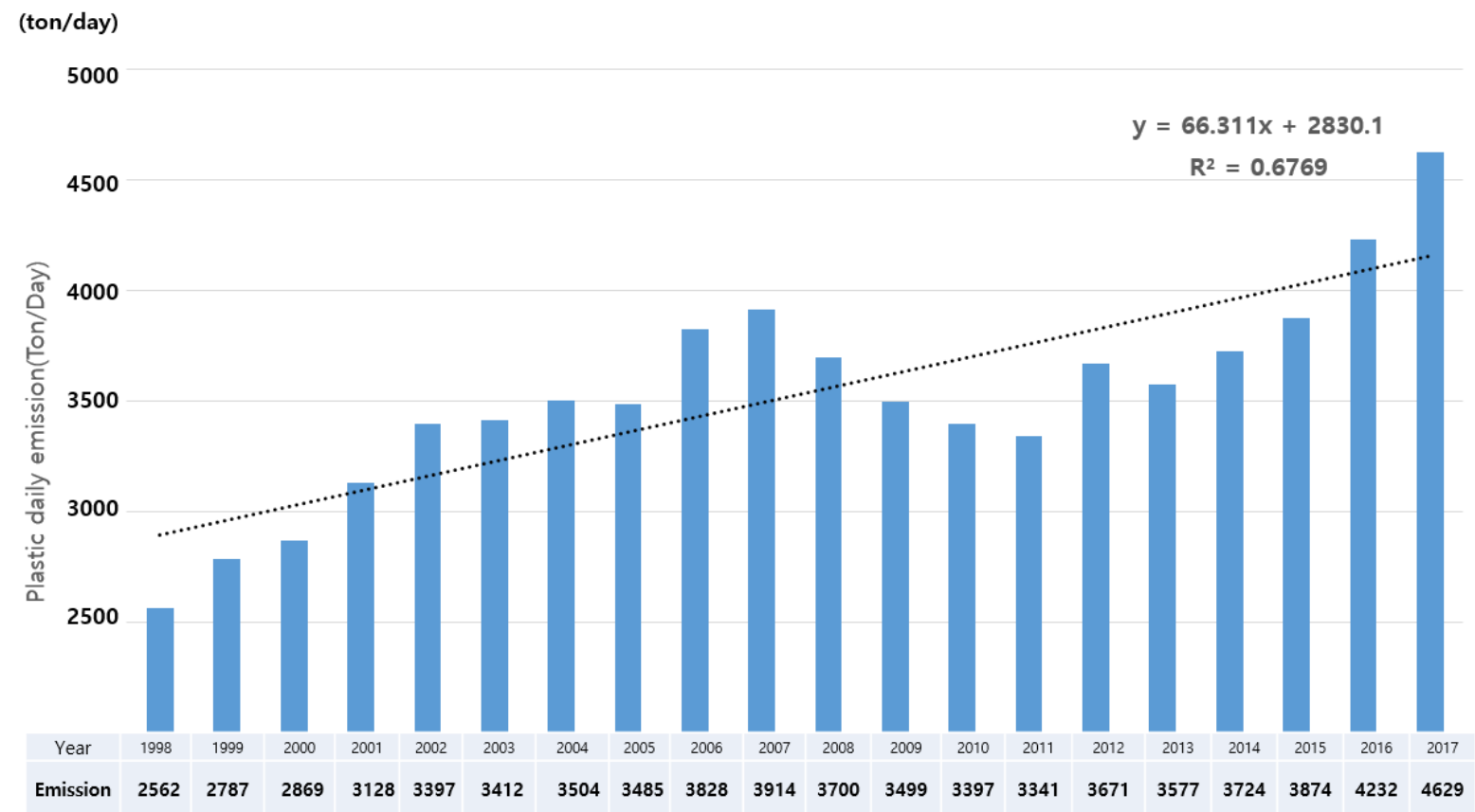

Figure 5. Trends in domestic plastic emissions in Korea over the last 20 years (1998-2017).

\section{(ton/day)}

3000

$y=-6.7388 x^{2}+159.2 x+1365.6$

$R^{2}=0.8407$

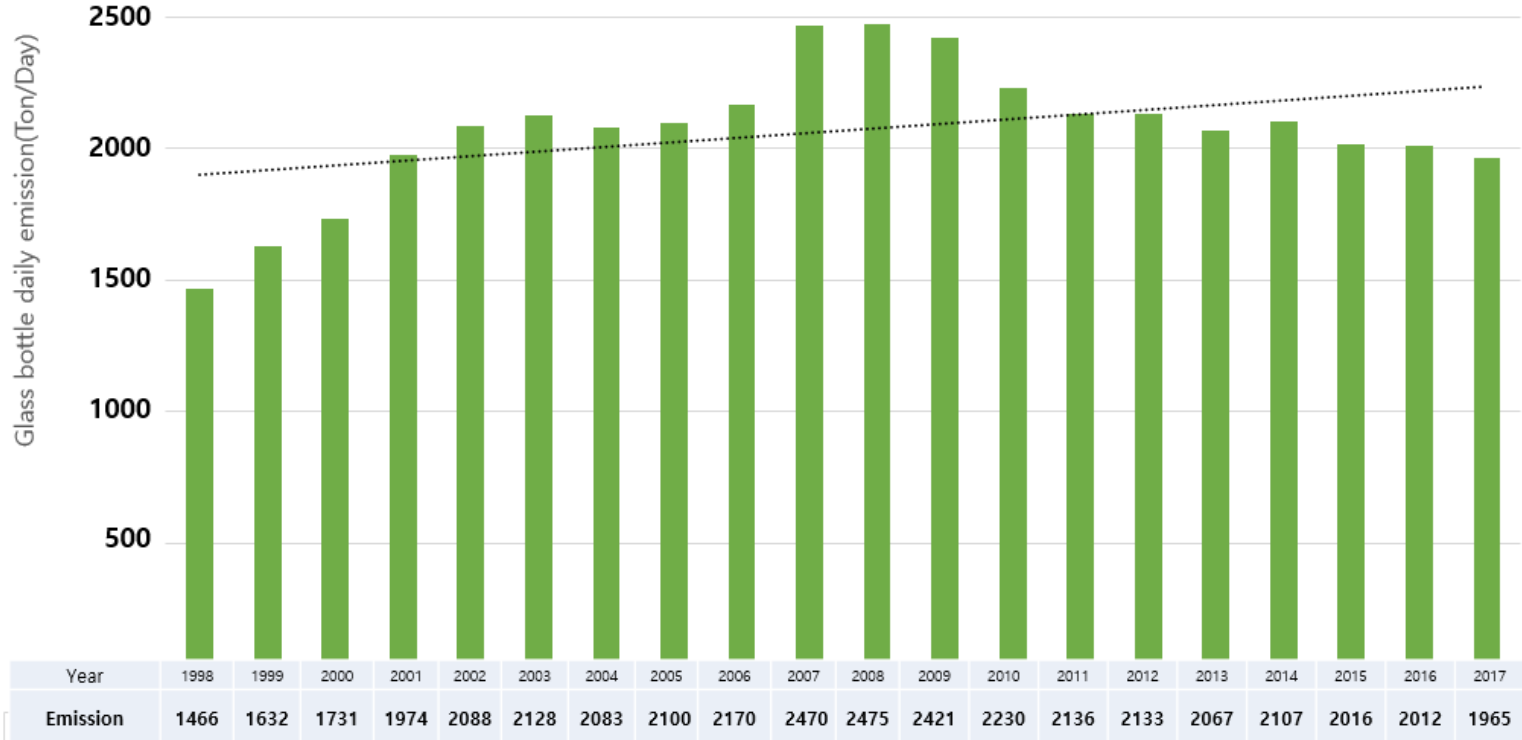

Figure 6. Trends in domestic glass-bottle emissions in Korea over the last 20 years (1998-2017). 


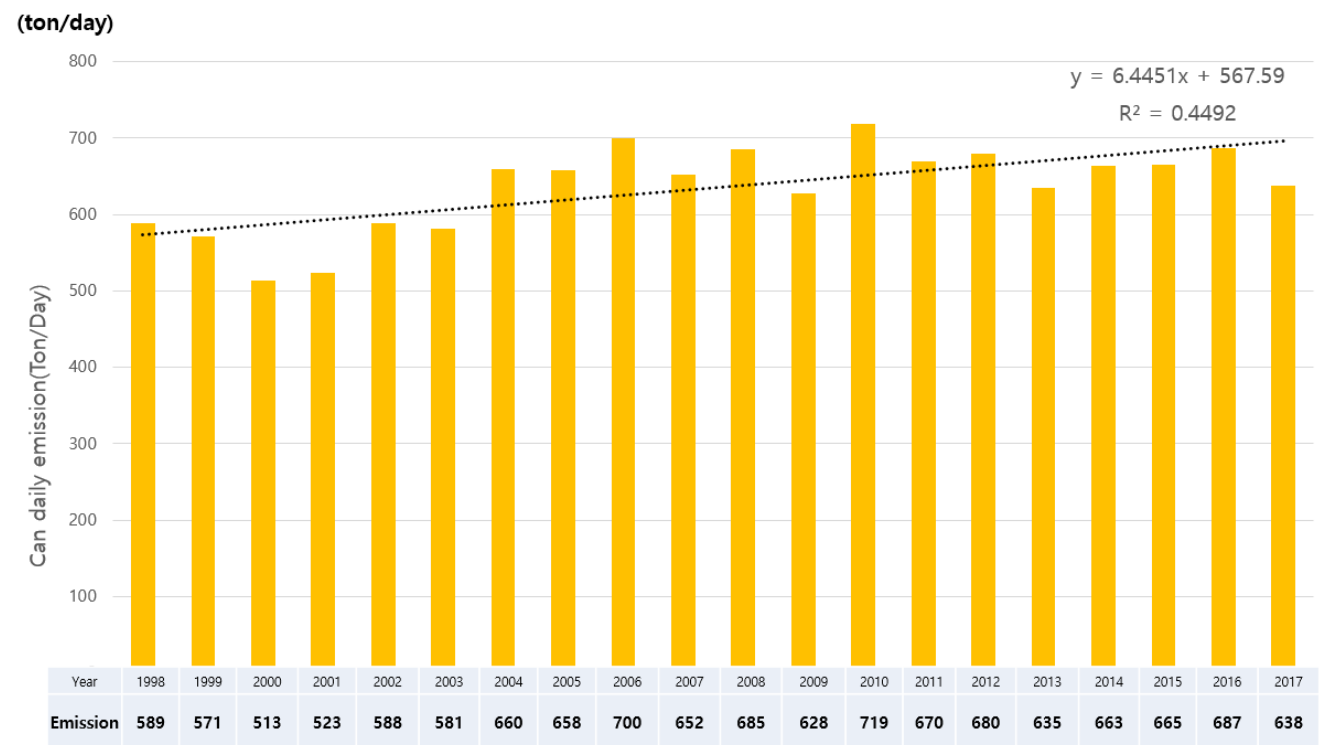

Figure 7. Trends in domestic cans emissions in Korea over the last 20 years (1998-2017).

Table 3 shows the analysis of the correlation between domestic waste emissions in 17 major regions in the last 20 years in Korea (1998-2017). The daily emissions of domestic waste for 20 years for plastics and glass bottles, plastics and cans, and glass bottles and cans showed a significant positive correlation. The daily discharge of domestic waste by year for 20 years of paper and plastic and paper and cans showed a significant negative correlation. This means that the amount of domestic waste from plastics, glass bottles, and cans shows similar fluctuations, while paper shows the opposite trend. As the daily output of plastics increases, it is expected that glass bottles and cans will increase, whereas paper will decrease.

Table 3. Correlation analysis of emissions between domestic waste.

\begin{tabular}{cccccc}
\hline & Paper & Plastic & Glass Bottle & Can & Total \\
\hline Paper & 1 & & & & \\
\hline Plastic & $-0.455^{*}$ & 1 & & & \\
\hline Glass bottle & -0.385 & $0.533^{*}$ & 1 & 1 & 1 \\
\hline Can & $-0.586^{* *}$ & $0.595^{* *}$ & $0.554^{*}$ & 0.084 & \\
\hline $\begin{array}{c}\text { Total } \\
\text { Emissions }\end{array}$ & $0.531^{*}$ & $0.456^{*}$ & 0.373 & &
\end{tabular}

The average daily discharge of domestic waste for the first 10 years from 1998 to 2007 was about 16,152 tons, which was about $3.5 \%$ higher than the average daily discharge of about 15,606 tons for the latter 10 years from 2008 to 2017 . This means that the daily discharge of paper waste, which accounts for about $61 \%$ of the total discharge, was on average 10,276 tons/day for the first 10 years from 1998 to 2007, more than 9019 tons/day than the latter 10 years from 2008 to 2017 is expected to receive. Among the four kinds of domestic wastes discharged in the last 20 years (1998-2017), the domestic waste and the degree of impact that affect the total amount of discharge were confirmed through the MRA method. Table 4 shows the results of the MRA results of variables on the total emissions of domestic waste. It was found that plastic and paper contribute about $89.6 \%$ of the total emissions. Plastics, glass bottles, cans, etc. were about $10 \%$ more than the average daily emissions for the first 10 years from 1998 to 2007 on average for the latter 10 years from 2008 to 2017. 
Table 4. MRA results of variables on total emissions of domestic waste.

\begin{tabular}{cccccc}
\hline \multicolumn{6}{c}{ Model Summary $^{\mathbf{b}}$} \\
\hline Model & $\mathbf{R}$ & $\mathbf{R}^{\mathbf{2}}$ & ${\text { Fixed } \mathbf{R}^{\mathbf{2}}}$ & Standard Error of Estimated Value & Durbin-Watson \\
\hline 1 & $0.947^{\text {a }}$ & 0.896 & 0.884 & 237.130 & 0.293 \\
\hline${ }^{\text {a }}$ Independent variable: Plastic, Paper. & ${ }^{\text {b }}$ Dependent variable: Total Emissions.
\end{tabular}

\subsection{A Survey on the Priority of Domestic Waste Recycling}

Table 5 shows the demographic analysis results of the 261 survey samples. As for the gender, the proportion of women was high, with $34.87 \%$ of men and $65.13 \%$ of women. As for age, about $27 \%$ were in their 20 s and 30 s, about $30 \%$ were in their 40 s and 50 s, and about $48 \%$ were in their 60 s and older. Unmarried people accounted for $12.64 \%$ and married people $87.36 \%$, most of whom were married. Income levels were generally evenly distributed. Jobs were divided into various occupation groups, including $28.74 \%$ of full-time housewives and $16.09 \%$ of professional jobs.

Table 5. Demographic characteristics of the survey respondents.

\begin{tabular}{|c|c|c|c|}
\hline Variable & Category & Frequency & Percentage \\
\hline \multirow{2}{*}{ Sex } & Male & 91 & 34.87 \\
\hline & Female & 170 & 65.13 \\
\hline \multirow{5}{*}{ Aged } & $20 \mathrm{~s}$ & 20 & 7.66 \\
\hline & $30 \mathrm{~s}$ & 34 & 13.03 \\
\hline & $40 \mathrm{~s}$ & 37 & 14.18 \\
\hline & $50 \mathrm{~s}$ & 43 & 16.48 \\
\hline & Over 60 & 127 & 48.66 \\
\hline \multirow{2}{*}{ Marital status } & Unmarried & 33 & 12.64 \\
\hline & Married & 228 & 87.36 \\
\hline \multirow{6}{*}{$\begin{array}{l}\text { Monthly } \\
\text { Salary }\end{array}$} & $\$ 900-\$ 1800$ & 39 & 14.94 \\
\hline & $\$ 1800-\$ 2700$ & 64 & 24.52 \\
\hline & $\$ 2700-\$ 3600$ & 58 & 22.22 \\
\hline & $\$ 3600-\$ 4500$ & 44 & 16.86 \\
\hline & $\$ 4500-\$ 5400$ & 35 & 13.41 \\
\hline & No answer & 21 & 8.05 \\
\hline \multirow{9}{*}{ Job } & Office technical position & 26 & 9.96 \\
\hline & Professional occupation & 42 & 16.09 \\
\hline & Sales & 15 & 5.75 \\
\hline & Managerial position & 10 & 3.83 \\
\hline & Self-employment & 25 & 9.58 \\
\hline & Housewife & 75 & 28.74 \\
\hline & Student & 3 & 1.15 \\
\hline & Not employed & 33 & 12.64 \\
\hline & Etc. & 32 & 12.26 \\
\hline
\end{tabular}

Table 6 shows the results of the survey on the perception of priority of 261 household waste recycling through AHP analysis. Plastics, vinyls, scrap metals, cans, papers, bottles, etc. were the types of household waste. Among the six kinds of household waste, plastics had a weight of 0.22 , which was the highest priority for recycling. Vinyls, scrap metals, and cans had the same priority, with a weight of 0.17 . Paper products had a weight of 
0.15 , which is the third priority, and bottle flows had a weight of 0.12 , showing the fourth priority for recycling among the six types of domestic waste.

Table 6. Results of a recycling priority recognition survey using AHP analysis.

\begin{tabular}{ccccccc}
\hline & Plastic & Vinyl & Scrap Metal & Can & Paper & Glass bottle \\
\hline Weight & 0.22 & 0.17 & 0.17 & 0.17 & 0.15 & 0.12 \\
\hline Priority & 1 & 2 & 2 & 2 & 3 & 4 \\
\hline
\end{tabular}

\section{Conclusions and Discussions}

The recycling policies of major countries, including Korea, the EU, China, and Japan, have changed to a cyclical economic paradigm in which recycling is recovered after consumption from a linear economy that is discarded after consumption, while the EU, Korea, and others include recognition of plastic-related problems and management strategies.

During the recent 20 years (1998-2017) of 17 major regions in Korea, the trend line analysis of daily emissions by four types of household wastes, such as paper, plastic, glass bottles, and cans, showed that the amount of discharge increased in the order of plastics and cans, and the discharge of paper showed a downward trend. The bottle showed a downward trend after the rise. Emissions of glass bottles showed an upward trend in the first 10 years (1998-2007), and the emission of glass bottles decreased in the latter 10 years (2008-2017).

In the correlation analysis, the daily discharge of household waste by year of plastics, glass bottles, and cans showed a significant positive correlation with each other, showing similar trends of change. As the daily output of plastics increases, it is expected that glass bottles and cans will increase, whereas paper will decrease. Through the MRA technique, it was found that plastics and paper have the most influence on the total emissions. Among the four types of household waste, plastics showed an upward trend and contributed significantly to the total emissions.

As a result of a survey on the perception of recycling priority using the AHP analysis method with 261 questionnaires with various demographic characteristics, the four kinds of household wastes had a weight, which is the priority for recycling in the order of plastic, cans, papers, and bottles. The demand for recycling was high for plastics and cans, which are household wastes with an increasing trend of discharge, and the demand for recycling for paper was low in the survey, which is household wastes with a downward trend.

Plastics among household wastes are recognized in the current recycling policies, such as EU and Korea, and are reflected in policies, such as management strategies. The daily emission of plastics also showed an upward trend, and the contribution to the total emission was high. In addition, in the recognition of recycling priority using the AHP analysis technique, plastic showed the highest recycling priority recognition. It showed the relationship between recycling policies, environmental conditions related to household waste emissions, and social awareness of recycling.

Paper is also an additional consideration. Paper emission is on the decline, and recycling priorities are low, but emissions are high, contributing to the total emissions. Therefore, additional attention and detailed management strategies are needed, such as action plans.

Author Contributions: Writing—original draft, Investigation, Statistical analysis, S.-h.J.; Conceptualization, Writing—Review \& Editing, Supervision, M.-h.L.; Survey, Statistical analysis, S.-h.L.; Supervision, Writing - review and editing, Funding acquisition, J.W.A. All authors have read and agreed to the published version of the manuscript.

Funding: This work was supported by the National Strategic Project-Carbon Mineralization Flagship Center of the National Reaseach Foundation of Korea (NRF) funded by the Ministry of Science and ICT (MSIT), the Ministry of Environment (ME) and the Ministry of Trade, Industry and Energy (MOTIE) 2019M3D8A2112963. 
Data Availability Statement: The authors declare that they have no known competing financial interests or personal relationships that could have appeared to influence the work reported in this paper.

Conflicts of Interest: The authors declare no conflict of interest.

\section{References}

1. Ministry of Environment. 1st Basic Plan for Resource Circulation (2018-2027); Ministry of Environment: Seoul, Korea, 2018.

2. Jeon, E. Policy Trends in Circular Economy by Major Countries; KEITI Konetic Report: Seoul, Korea, 2019.

3. Lee, S. Circular Economy \& Plastic Policy Trends and Management Strategies; KEITI Konetic Report: Seoul, Korea, 2019.

4. Ministry of Environment. 2000 The National Waste Generation and Treatment; Seoul, Korea; 2001. Available online: http://www.me. go.kr/home/file/readDownloadFile.do?fileId=2391\&fileSeq=1/ (accessed on 1 February 2019).

5. Ministry of Environment. 2001 The National Waste Generation and Treatment. Seoul, Korea. 2002. Available online: http: //www.kwaste.or.kr/bbs/content.php?co_id=sub0401/ (accessed on 1 February 2019).

6. Ministry of Environment. 2002 The National Waste Generation and Treatment. Seoul, Korea. 2003. Available online: https: / / www.recycling-info.or.kr/rrs/stat/envStatList.do?menuNo=M13020201/ (accessed on 1 February 2019).

7. Ministry of Environment. 2003 The National Waste Generation and Treatment. Seoul, Korea. 2004. Available online: https: / / www.recycling-info.or.kr/rrs/stat/envStatList.do?menuNo=M13020201/ (accessed on 1 February 2019).

8. Ministry of Environment. 2004 The National Waste Generation and Treatment. Seoul, Korea. 2005. Available online: https: / / www.recycling-info.or.kr/rrs/stat/envStatList.do?menuNo=M13020201/ (accessed on 1 February 2019).

9. Ministry of Environment. 2005 The National Waste Generation and Treatment. Seoul, Korea. 2006. Available online: https: / / www.recycling-info.or.kr/rrs/stat/envStatList.do?menuNo=M13020201/ (accessed on 1 February 2019).

10. Ministry of Environment. 2006 The National Waste Generation and Treatment. Seoul, Korea. 2007. Available online: https: / / www.recycling-info.or.kr/rrs/stat/envStatList.do?menuNo=M13020201/ (accessed on 1 February 2019).

11. Ministry of Environment. 2007 The National Waste Generation and Treatment. Seoul, Korea. 2008. Available online: https: / / www.recycling-info.or.kr/rrs/stat/envStatList.do?menuNo=M13020201/ (accessed on 1 February 2019).

12. Ministry of Environment. 2008 The National Waste Generation and Treatment. Seoul, Korea. 2009. Available online: https: / / www.recycling-info.or.kr/rrs/stat/envStatList.do?menuNo=M13020201/ (accessed on 1 February 2019).

13. Ministry of Environment. 2009 The National Waste Generation and Treatment. Seoul, Korea. 2010. Available online: https: / / www.recycling-info.or.kr/rrs/stat/envStatList.do?menuNo=M13020201/ (accessed on 1 February 2019).

14. Ministry of Environment. 2010 The National Waste Generation and Treatment. Seoul, Korea. 2011. Available online: https: / / www.recycling-info.or.kr/rrs/stat/envStatList.do?menuNo=M13020201/ (accessed on 1 February 2019).

15. Ministry of Environment. 2011 The National Waste Generation and Treatment. Seoul, Korea. 2012. Available online: https: / / www.recycling-info.or.kr/rrs/stat/envStatList.do?menuNo=M13020201/ (accessed on 1 February 2019).

16. Ministry of Environment. 2012 The National Waste Generation and Treatment. Seoul, Korea. 2013. Available online: https: / / www.recycling-info.or.kr/rrs/stat/envStatList.do?menuNo=M13020201/ (accessed on 1 February 2019).

17. Ministry of Environment. 2013 The National Waste Generation and Treatment. Seoul, Korea. 2014. Available online: https: / / www.recycling-info.or.kr/rrs/stat/envStatList.do?menuNo=M13020201/ (accessed on 1 February 2019).

18. Ministry of Environment. 2014 The National Waste Generation and Treatment. Seoul, Korea. 2015. Available online: https: / / www.recycling-info.or.kr/rrs/stat/envStatList.do?menuNo=M13020201/ (accessed on 1 February 2019).

19. Ministry of Environment. 2015 The National Waste Generation and Treatment. Seoul, Korea. 2016. Available online: https: / / www.recycling-info.or.kr/rrs/stat/envStatList.do?menuNo=M13020201/ (accessed on 1 February 2019).

20. Ministry of Environment. 2016 The National Waste Generation and Treatment. Seoul, Korea. 2017. Available online: https: / / www.recycling-info.or.kr/rrs/stat/envStatList.do?menuNo=M13020201/ (accessed on 1 February 2019).

21. Ministry of Environment. 2017 The National Waste Generation and Treatment. Seoul, Korea. 2018. Available online: https: / / www.recycling-info.or.kr/rrs/stat/envStatList.do?menuNo=M13020201/ (accessed on 22 October 2020).

22. Ministry of Environment. 2018 The National Waste Generation and Treatment. Seoul, Korea. 2019. Available online: https: / / www.recycling-info.or.kr/rrs/stat/envStatList.do?menuNo=M13020201/ (accessed on 31 December 2020).

23. Korean Statistical Information Service. Available online: https://kosis.kr/eng/ (accessed on 22 October 2020).

24. Korea Resource Recirculation Information System. Available online: https://www.recycling-info.or.kr/rrs/main.do (accessed on 22 October 2020).

25. Korea Waste Association. Available online: http://www.kwaste.or.kr/bbs/content.php?co_id=sub0401 (accessed on 22 October 2020).

26. Min, D. Studies on the Implementation Plan for Introduction of Circular Economy; The National Institute of Environmental Research: Seoul, Korea, 2018.

27. European Commission. Closing the Loop-An EU Action Plan for the Circular Economy. COM. 2015. Available online: https:/ / ec.europa.eu/transparency/regdoc/rep/1/2015/EN/1-2015-614-EN-F1-1.PDF (accessed on 22 October 2020).

28. European Commission. A European Strategy for Plastics in a Circular Economy. COM. 2018. Available online: https:// eur-lex.europa.eu/resource.html?uri=cellar:2df5d1d2-fac7-11e7-b8f5-01aa75ed71a1.0001.02/DOC_1\&format=PDF (accessed on 22 October 2020). 
29. European Commission. A New Circular Economy Action Plan for a Clean and More Competitive Europe; European Commission: Brussels, Belgium, 2020. Available online: https:/ / ec.europa.eu/environment/circular-economy/ (accessed on 23 October 2020).

30. European Commission. Available online: https:/ / ec.europa.eu/environment/circular-economy/ (accessed on 22 October 2020).

31. Oh, T. EU Circular Economic Strategy and Regulation of Plastic Use; Korea Institute for International Economic Policy: Seoul, Korea, 2018.

32. Park, H. Key Contents and Implications of EU's New Circular Economic Action Plan; Consumer Agency: Seoul, Korea, 2020.

33. Institute European Environmental Policy. Available online: https://ieep.eu/publications/an-analysis-of-the-new-eu-circulareconomy-action-plan (accessed on 23 October 2020).

34. Ministry of the Interior and Safety. Administrative Operations Manual. 2018. Available online: https://www.korea.kr/archive/ expDocView.do?docId=37985 (accessed on 22 October 2020).

35. Ministry of the Interior and Safety. Public Hearing Operation Manual. 2018. Available online: https://www.korea.kr/archive/ expDocView.do?docId=37983 (accessed on 22 October 2020).

36. Korea Law Information Center. Available online: WWW.LAW.GO.KR (accessed on 23 October 2020).

37. Jung, Y.; Nam, H. A Development of the Post-Evaluation Index about Maintenance of Remains by using Delphi and AHP Method. J. Archit. Hist. 2014, 23, 19-33. [CrossRef]

38. Song, K.; Lee, Y. Re-scaling for Improving the Consistency of the AHP Method. Soc. Sci. Res. Rev. 2013, 29, $271-288$.

39. Lee, H.; Kim, S.; Lee, S. A Study on Priority for Standardization of Healthcare Devices Using the AHP Model. J. Korea Soc. Health Inform. Stat. 2013, 38, 143-153.

40. Lipovetsky, S.; Conklin, W. Robust estimation of priorities in the AHP. Eur. J. Oper. Res. 2002, 137, 110-122. [CrossRef]

41. Yonhapnews. Available online: https:/ / www.yna.co.kr/view / RPR20190722005400353 (accessed on 20 November 2020).

42. Nocutnews. Opening of the Korea Carbon Forum. 2019. Available online: https://www.nocutnews.co.kr/news/5207925 (accessed on 20 November 2020).

43. Yoo, K. Analysis of the success factors of sports events by local governments using AHP. Int. J. Sport Manag. Mark. 2010, 15, 91-102.

44. Cho, G.; Cho, Y.; Kang, H. Hierarchical Decision Making; Donghyun Publishing: Seoul, Korea, 2010.

45. Jung, B. Analysis of the priority of road projects using AHP. J. Korean Transp. Assoc. 2002, 20, 45-54.

46. Hong, S.; Hyun, J. AHP Analysis Techniques for the Weighted Evaluation of Cultural Heritage Disaster Safety Management Systems. J. Korean Soc. Hazard Mitig. 2018, 18, 43-53.

47. Sohn, S.; Kim, S. Effect of the importance and utilization of performance metric using ahp technique on management performance. Rev. Account. Policy Stud. 2012, 17, 375-397.

48. Lee, C. Group Decision Making; Sejong Publishing: Seoul, Korea, 2000. 